\title{
IS POLAND AN INNOVATIVE COUNTRY?
}

\author{
Dorota CHYBOWSKA, Leszek CHYBOWSKI \\ Maritime University of Szczecin \\ Valeri SOUCHKOV \\ University of Twente
}

\begin{abstract}
:
The potential for innovativeness is difficult to measure, though many have attempted to do so. In order to look at Poland's innovation potential, its current position and its opportunity to grow, compared with developing and developed countries, this study analysed the patent statistics of the Polish and European Patent Offices. Poland has been a member of the European Union for over a decade now. Therefore, we took into consideration the statistics for patent applications and grants for the last decade, up to the first quarter of 2016. The questions we wanted to answer concerned not only the technology fields that Poland patented its inventions in, but also the types of patent grantees and applicants. In order to determine why Poland is still considered to be only a moderate innovator by the Innovation Union Scoreboard, we also gathered information on Polish inventors abroad in 2015 and the first quarter of 2016, to see their number, technology fields, and types of patent grantees. Finally, we attempted to identify the main barriers that seem to inhibit Polish technology and innovation growth, despite significantly growing R\&D intensities (up from 0.56 GDP and EUR 1,139 $M$ in 2004 to 0.94 GDP and EUR 3,864 M in 2014).
\end{abstract}

Key words: innovativeness potential, inventions, patent mining, innovation, Poland

\section{INTRODUCTION}

As Genrich Altshuller observed, "inventing is the oldest human activity" [1]. Humans have always faced problems to solve otherwise they would not have advanced. We could attempt to categorise inventions into cutting-edge, unique, lucrative, local, global, etc. while searching for the motivators that bring them to light. Regardless of their origin, however, inventions are an expression of human creativity, concentration, reasoning and critical thinking.

Pursuant to international treaties, a patent is a confirmation of novelty and usefulness of an invention for the state of the art. It is also an exclusive right granted to the inventor. Disclosing an invention to a patent office in return for an inventor's monopoly to use it has equally many supporters and opponents. On the one hand, the patent system is easily accessible and open, whereas on the other it discloses inventive ideas to competitors.

We could provide many examples of patent wars, not only those of the 20th and 21st centuries, and discuss whether or not they affected technological progress. Undoubtedly, without the exchange of ideas through disclosing inventions, we would not move forward and the wheel would have to be reinvented not once but an infinite number of times.

Altshuller, who introduced the theory of inventive problem solving, claimed that every person can become an inventor. Not necessarily a good one, but an inventor nevertheless. Our paper does not conclude which nation is the world's most inventive one. Although we would like to know this ourselves, we fear that answering this question is impossible. In this paper we concentrate on our own country and we attempt to show the place of Polish inventive problem solving and Polish inventors in the system of invention disclosure exchange in the last decade. The purpose of the paper is to offer a review of the statistics of Polish and European Patent Offices for the last decade and to compare Poland to other countries in terms of inventions, inventive potential and barriers. We also test the hypothesis that Polish inventors invent abroad. Despite growing Polish R\&D intensities, the world still considers Poland a moderate innovator and every year many statistics appear to support this view.

\section{POLAND VERSUS OTHER COUNTRIES}

Poland, with its $38.5 \mathrm{M}$ inhabitants, is the 6th largest country in the European Union by population, after Germany, France, UK, Italy and Spain [17]. In 2014 there were $1,469,386$ Polish university graduates and 319,019 of them graduated from technical universities, which makes $21 \%$ of all graduates [11]. Moreover, Polish R\&D intensities grew from 0.56 GDP and EUR 1,139 M in 2004 to 0.94 GDP and EUR 3,864 $M$ in 2014 [10] while R\&D personnel numbered 153,500 in 2014 [5].

To assess if the Polish potential expressed by its population, number of university graduates, R\&D personnel and growing investments in the R\&D sector correlates with the number of inventions, we analysed statistics published by the Polish and European Patent Offices. We considered the 
number of applications and granted patents between 2006 and 2015, filed by and given to both Polish and non-Polish grantees.

Tables 1 and 2 present the number of applications and patents granted by the Polish Patent Office (UP RP), respectively. The annual number of applications to the UP RP in the period 2006-2015 increased by more than $100 \%$ for Polish applicants. For foreign applicants, the annual number of applications decreased, from 212 in 2006 to 99 in 2015. In percentage terms: in 2006 Polish applications made up $91.0 \%$ of all applications, and in 2015, 98.0\%; and in 2008 foreign patent grantees made up almost $60.0 \%$ of the total, while in 2015 they only accounted for $6.5 \%$ of grantees.

Table 1

Polish Patent Office (UP RP) - number of applications 2006-2015

\begin{tabular}{lrrrrr}
\hline Year & $\mathbf{2 0 0 6}$ & $\mathbf{2 0 0 7}$ & $\mathbf{2 0 0 8}$ & $\mathbf{2 0 0 9}$ & $\mathbf{2 0 1 0}$ \\
\hline Polish & 2157 & 2392 & 2488 & 2899 & 3203 \\
Foreign & 212 & 214 & 232 & 241 & 227 \\
TOTAL & 2369 & 2606 & 2720 & 3140 & 3430 \\
Year & 2011 & 2012 & 2013 & 2014 & 2015 \\
Polish & 3878 & 4410 & 4237 & 3941 & 4674 \\
Foreign & 245 & 247 & 174 & 155 & 99 \\
TOTAL & 4123 & 4657 & 4411 & 4096 & 4773 \\
\hline
\end{tabular}

Source: Authors' analysis based on [2, 16].

Table 2

Polish Patent Office (UP RP) - number of patent grants 2006-2015

\begin{tabular}{lcrrrr}
\hline Year & $\mathbf{2 0 0 6}$ & $\mathbf{2 0 0 7}$ & $\mathbf{2 0 0 8}$ & $\mathbf{2 0 0 9}$ & $\mathbf{2 0 1 0}$ \\
\hline Polish & & & 1451 & 1536 & 1385 \\
Foreign & $2686^{*}$ & $3534^{*}$ & 2139 & 2422 & 1619 \\
TOTAL & 2686 & 3534 & 3590 & 3958 & 3004 \\
Year & 2011 & 2012 & 2013 & 2014 & 2015 \\
Polish & 1989 & 1848 & 2339 & 2490 & 2404 \\
Foreign & 1123 & 636 & 465 & 262 & 168 \\
TOTAL & 3112 & 2484 & 2804 & 2752 & 2572 \\
\hline
\end{tabular}

Source: Authors' analysis based on $[2,16]$.

Tables 3 and 4 show the annual number of applications and patents granted by the European Patent Office (EPO) between 2006 and 2015.

Table 3

European Patent Office (EPO) - number of applications 2006-2015

\begin{tabular}{lrrrrr}
\hline Year & \multicolumn{1}{c}{$\mathbf{2 0 0 6}$} & \multicolumn{1}{c}{$\mathbf{2 0 0 7}$} & \multicolumn{2}{c}{$\mathbf{2 0 0 8}$} & \multicolumn{2}{c}{$\mathbf{2 0 0 9}$} & \multicolumn{1}{c}{$\mathbf{2 0 1 0}$} \\
\hline Polish & 125 & 104 & 168 & 174 & 205 \\
Foreign & 135233 & 141127 & 146076 & 134337 & 150810 \\
TOTAL & 135358 & 141231 & 146244 & 134511 & 151015 \\
Year & 2011 & 2012 & 2013 & 2014 & 2015 \\
Polish & 246 & 383 & 372 & 482 & 568 \\
Foreign & 142576 & 148179 & 147655 & 152221 & 159454 \\
TOTAL & 142822 & 148562 & 148027 & 152703 & 160022 \\
\hline
\end{tabular}

Source: Authors' analysis based on [8, 9].
Table 4

European Patent Office (EPO) - number of patent grants 2006-2015

\begin{tabular}{lrrrrr}
\hline Year & $\mathbf{2 0 0 6}$ & $\mathbf{2 0 0 7}$ & $\mathbf{2 0 0 8}$ & $\mathbf{2 0 0 9}$ & $\mathbf{2 0 1 0}$ \\
\hline Polish & 17 & 27 & 26 & 33 & 44 \\
Foreign & 62760 & 54673 & 59774 & 51919 & 58073 \\
TOTAL & 62777 & 54700 & 59800 & 51952 & 58117 \\
Year & 2011 & 2012 & 2013 & 2014 & 2015 \\
Polish & 45 & 80 & 95 & 108 & 150 \\
Foreign & 62063 & 65575 & 66617 & 64505 & 68271 \\
TOTAL & 62108 & 65655 & 66712 & 64613 & 68421 \\
\hline
\end{tabular}

Source: Authors' analysis based on [8, 9].

Data analysis shows that Polish patent applications increased 4.5 times between 2006 and 2015 while the number of patent grants to Polish grantees increased 8.8 times. However, the absolute number of Polish patent applications and grants is insignificant when compared to the totals of applications and grants by the EPO in the period: Polish applications to the EPO in 2015 equalled $0.35 \%$ of the total number of applications while the number of patents granted to Polish grantees amounted to $0.22 \%$. These data clearly indicate that Polish applicants get patents locally - they patent inventions 16 times more often in Poland than through the EPO. The number of patents granted to Polish owners by the EPO equals only $6.0 \%$ of patents granted to Polish owners by the UP RP.

In Figure 1 we present a comparison between Poland and selected developed countries in terms of patent grants by the EPO.

Statistical analysis revealed that $22.15 \%$ of all patents granted by the EPO in the period were American (USA), 21.32\% German, 18.21\% Japanese, 7.56\% French, 2.34\% South Korean, 1.15\% Finish and 0.99\% Chinese.

As seen in Figure 1, countries from the same region (here, Asia) can differ significantly. Awareness and intellectual property rights (IPR) culture might be the underlying reason for these differences. Polish patents amount to only $0.10 \%$ of the total number of patents granted by the EPO in the period.

\section{TYPE OF GRANTEE}

The available reports [7] indicate that in Poland the governmental sector still has the biggest share in the R\&D financing structure (45.2\% in 2014). The share of the private sector increased to $39.0 \%$ (i.e. by 14.6 percentage points) in comparison to 2010. The research (educational) sector invests the least in R\&D (2.2\%) [5]. Concerning the internal $R \& D$ expenses by sector, the private sector leads the way at $47.0 \%$, with the research sector at $29.0 \%$ and governmental at $24.0 \%$.

Figure 2 shows the results of our analysis of patents granted in 2015 and the 1st quarter of 2016 by the EPO to Polish and foreign grantees, but with a Polish (co)inventor. It also shows that in terms of the type of patent grantee, enterprises take the lead (both Polish and foreign with a Polish (co)inventor). The research sector is placed second, but its figures refer exclusively to Polish patent owners.

Table 5 shows the ranking of the top 5 Polish grantees in the EPO in 2015. The most patents were granted to enterprises, with International Tobacco Machinery Poland Sp. z o.o. from Radom and FAKRO PP Sp. z o.o. from Nowy Sącz leading the field. Other enterprises making up the total received 1-2 patents each. 


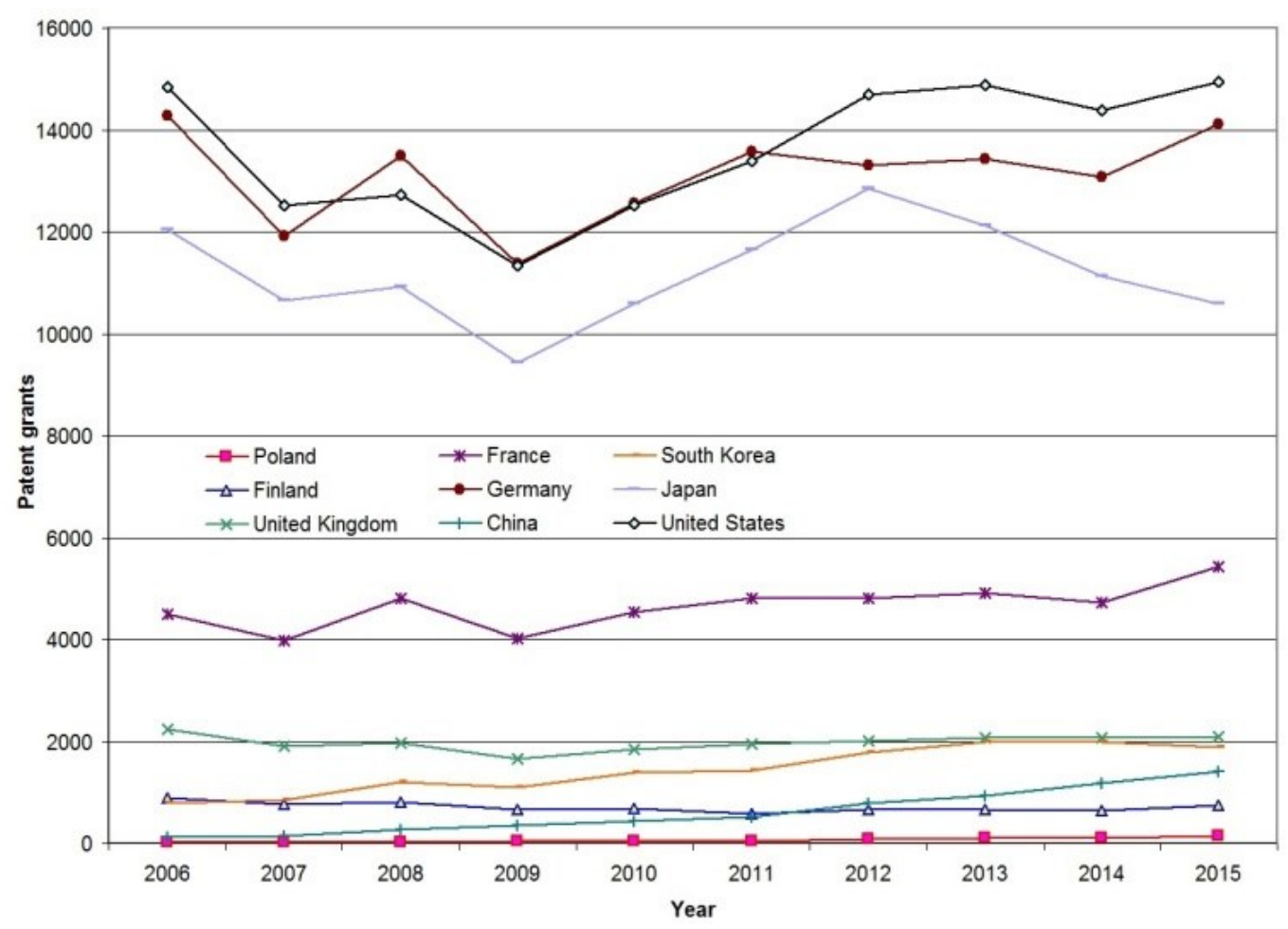

Fig. 1 Poland vs. selected developed countries - patent grants by the European Patent Office (EPO) 2006-2015 Source: Authors' analysis based on [7, 9].

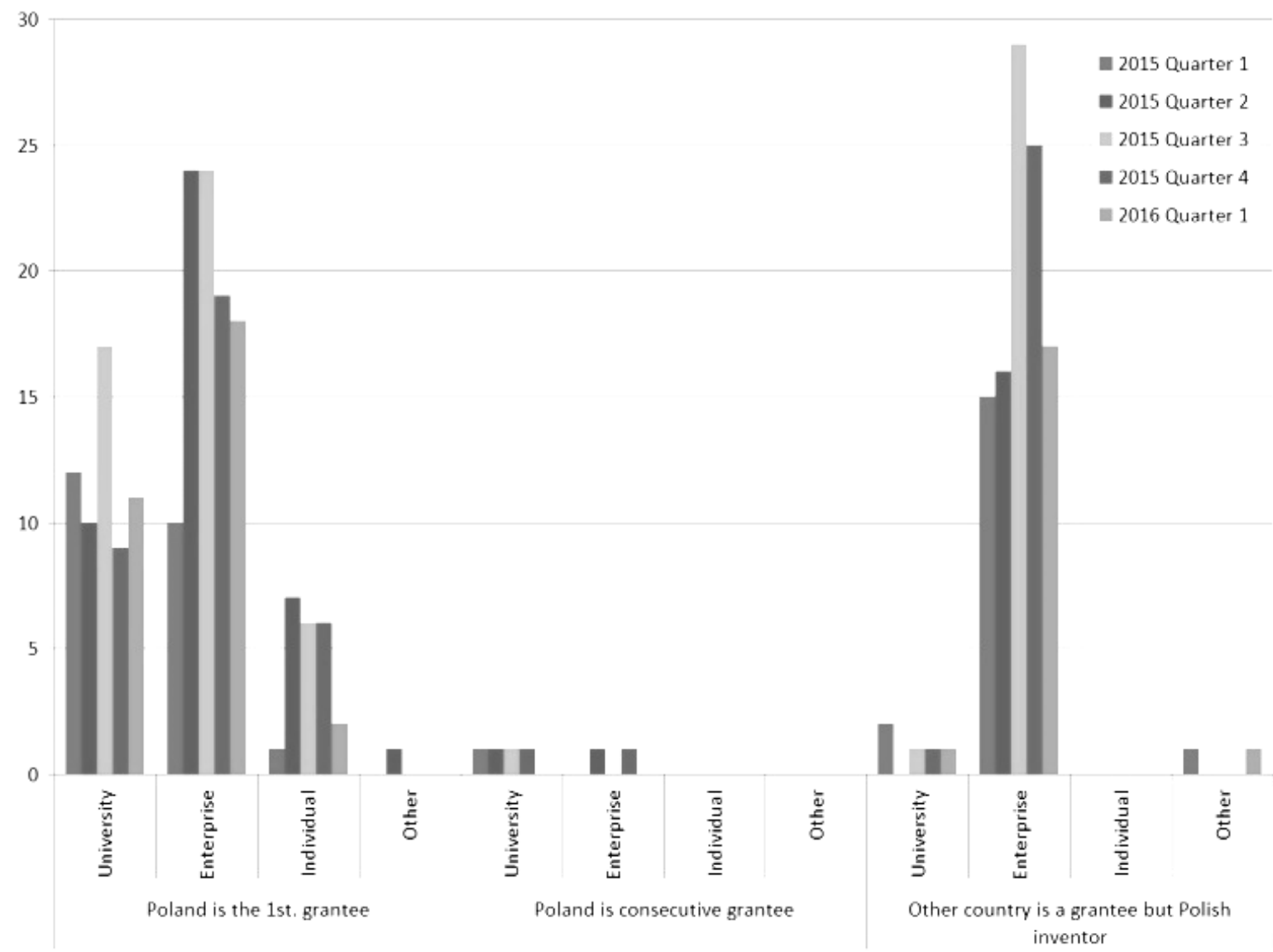

Fig. 2 Distribution of patents granted in 2015 and the 1st quarter of 2016 by the European Patent Office (EPO) to Polish grantees and foreign grantees with Polish inventors

Source: Authors' analysis. 
The position of the research sector is also strong, both in terms of patent grants, as shown in Table 5, and (according to the information presented in [9]) patent applications: in 2015 Gdańsk University of Technology filed the most patent applications (23), followed by AGH University of Science and Technology in Cracow (22), International Tobacco Machinery Poland Sp. z o.o. (14) and HS Wrocław Sp. z o.o. (11).

Table 5

European Patent Office (EPO) - Ranking of Top 5 Polish grantees in 2015.

\begin{tabular}{|c|c|c|}
\hline Grantee & $\begin{array}{c}\text { Status } \\
\left(E, R, I, O^{*}\right) \\
\end{array}$ & 2015 \\
\hline International Tobacco & $E$ & 9 \\
\hline $\begin{array}{l}\text { Machinery Poland Sp. z o.o., } \\
\text { Radom, Mazovian }\end{array}$ & & \\
\hline $\begin{array}{l}\text { AGH University of Science } \\
\text { and Technology }\end{array}$ & $\mathrm{R}$ & 6 \\
\hline Cracow, Lesser Poland & & \\
\hline $\begin{array}{l}\text { FAKRO PP Sp. z o.o. } \\
\text { Nowy Sącz, Lesser Poland }\end{array}$ & $\mathrm{E}$ & 6 \\
\hline $\begin{array}{l}\text { Institute of Immunology } \\
\text { and Experimental Therapy }\end{array}$ & $\mathrm{R}$ & 4 \\
\hline $\begin{array}{l}\text { Polish Academy of Sciences, } \\
\text { Wrocław, Lower Silesian }\end{array}$ & & \\
\hline Warsaw University & $\mathrm{R}$ & 4 \\
\hline Warsaw, Mazovian & & \\
\hline TOTAL & & 29 \\
\hline
\end{tabular}

*E for enterprises, $\mathrm{R}$ for universities, research institutes, I for individual grantees, $\mathrm{O}$ for other types (NGO, hospital etc.)

In the UP RP, the research sector dominates as a patent grantee. Table 6 presents the ranking of the top 5 grantees in the 1st quarter of 2016.

Table 6

Polish Patent Office (UP RP) - Ranking of Top 5 Polish grantees in 1st quarter of 2016.

\begin{tabular}{lcc}
\hline Grantee & $\begin{array}{c}\text { Status } \\
\left(\mathbf{E}, \mathbf{R}, \mathbf{l}, \mathbf{O}^{*}\right)\end{array}$ & Patents \\
\hline $\begin{array}{l}\text { Wrocław University of Technology } \\
\text { Wrocław, Lower Silesian }\end{array}$ & $\mathrm{R}$ & 20 \\
$\begin{array}{l}\text { AGH University of Science } \\
\text { and Technology }\end{array}$ & $\mathrm{R}$ & 18 \\
$\begin{array}{l}\text { Cracow, Lesser Poland } \\
\text { Lublin University of Technology }\end{array}$ & $\mathrm{R}$ & 15 \\
$\begin{array}{l}\text { Lublin } \\
\begin{array}{l}\text { West Pomeranian University } \\
\text { of Technology }\end{array}\end{array}$ & \\
$\begin{array}{l}\text { Szczecin, West Pomeranian } \\
\text { Warsaw University of Technology }\end{array}$ & $\mathrm{R}$ \\
$\begin{array}{l}\text { Warsaw, Mazovian } \\
\text { TOTAL }\end{array}$ & $\mathrm{R}$ & 14 \\
\hline
\end{tabular}

${ }^{*} \mathrm{E}$ for enterprises, $\mathrm{R}$ for universities, research institutes, I for individual grantees, $\mathrm{O}$ for other types (NGO, hospital etc.)

To compare, we also analysed foreign grantees in the Polish Patent Office (UP RP) in the 1st quarter of 2016 as shown in Table 7. Most patents (93\%) were granted to enterprises.
Table 7

Polish Patent Office (UP RP) - Ranking of Top 5 foreign grantees 1st quarter of 2016

\begin{tabular}{lccc}
\hline Grantee & $\begin{array}{c}\text { Status } \\
\left(\mathbf{E}, \mathbf{R}, \mathbf{l}, \mathbf{O}^{*}\right)\end{array}$ & Country & Patents \\
\hline VKR Holding A/S & $\mathrm{E}$ & Denmark & 4 \\
General Electric Company & $\mathrm{E}$ & USA & 3 \\
Joy MM Delaware, Inc. & $\mathrm{E}$ & USA & 3 \\
Soho Flordis International & & & \\
Pty Ltd. & $\mathrm{E}$ & Austria & 3 \\
Janssen Pharmaceutica N.V. & $\mathrm{E}$ & Belgium & $\mathbf{2}$ \\
TOTAL & & & $\mathbf{1 5}$ \\
\hline
\end{tabular}

*E for enterprises, $\mathrm{R}$ for universities, research institutes, I for individual grantees, $\mathrm{O}$ for other types (NGO, hospital etc.)

In the 1st quarter of 2016, the Polish Patent Office granted 607 patents, 44 of which were to foreign owners (mostly from the USA - 17 and Germany - 9). As for Polish grantees, 287 patents were granted to universities and research institutes (47.0\% of all granted patents), 186 to enterprises (31.0\%) and 89 to individuals. Polish patents make up $93.0 \%$ of all patents granted by the Polish Patent Office in the 1 st quarter of 2016.

\section{REGIONAL DISTRIBUTION OF POLISH PATENT GRANTEES}

Poland consists of 16 administrative districts (voivodeships). Both Polish and European statistics for 2015, shown in Figure 3, place Mazovian, Silesian and Lesser Poland voivodeships as leaders of invention disclosure.

According to [8], in 2015 the leading geographic regions in Poland, in terms of patent applications, were Mazovian (149 applications; $26.0 \%$ share in all Polish applications), Lesser Poland $(79 ; 14.0 \%)$ and Pomeranian (70; 12.0\%).

\section{POLISH INVENTORS}

To investigate why the number of Polish patents is still so low at the European level (163 from 01 Jan 2015 to 31 March 2016), we analysed data from the EPO for the same period and compared the results with the number of foreign grantees where a Polish inventor was identified. We found 109 such patents: in 26 of them, the inventors were exclusively Polish. Table 8 presents the ranking of the top 8 foreign grantees with Polish inventors in 2015.

Table 8

European Patent Office (EPO) - Ranking of Top 8 foreign grantees with Polish inventors in 2015

\begin{tabular}{llc}
\hline Grantee & Country & 2015 \\
\hline ABB Technology AG & Switzerland & 12 \\
BSH Hausgeräte GmbH & Germany & 5 \\
CCS Technology, Inc. & USA & 4 \\
Lonza Ltd. & Switzerland & 4 \\
Mentor Graphics Corporation & USA & 4 \\
Bombardier Transportation GmbH & Germany & 3 \\
General Electric Company & USA & 3 \\
Nokia Solutions and Networks Oy & Finland & 3 \\
TOTAL & & $\mathbf{3 8}$ \\
\hline
\end{tabular}


The Poles invent mainly for companies, most of them from Switzerland $(25.0 \%$ of patents granted between 01 January 2015 to 31 March 2016), Germany (24.0\%) and the USA (19.0\%).

a)

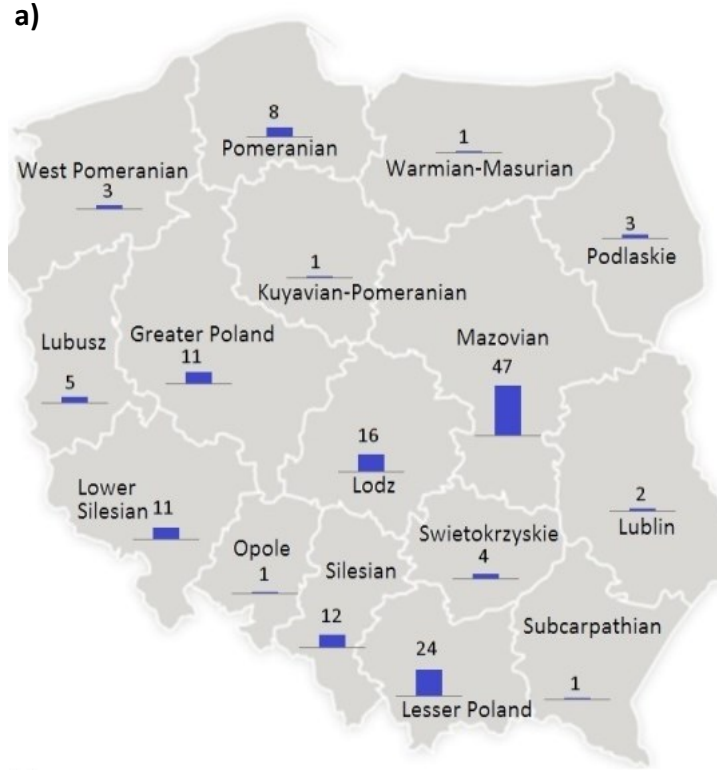

\section{THE KEY FIELDS OF POLISH INVENTORS}

The data we retrieved from the European Patent Office for 2015 in terms of technology fields where Polish inventors were involved are shown in Figure 4.

b)

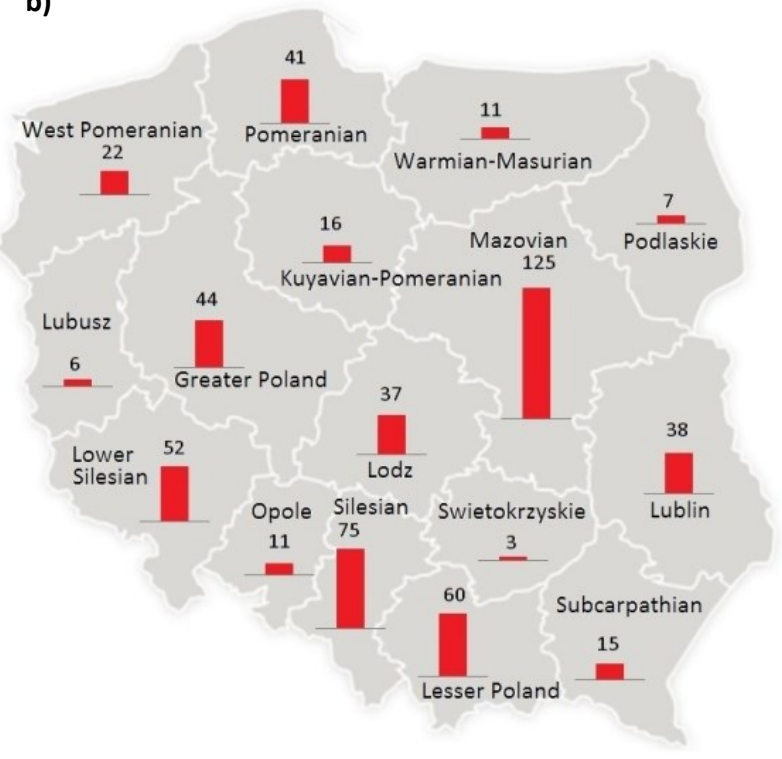

Fig. 3 Regional distribution of Polish patent grantees in 2015; a) - European Patent Office (EPO), b) - Polish Patent Office (UP RP)

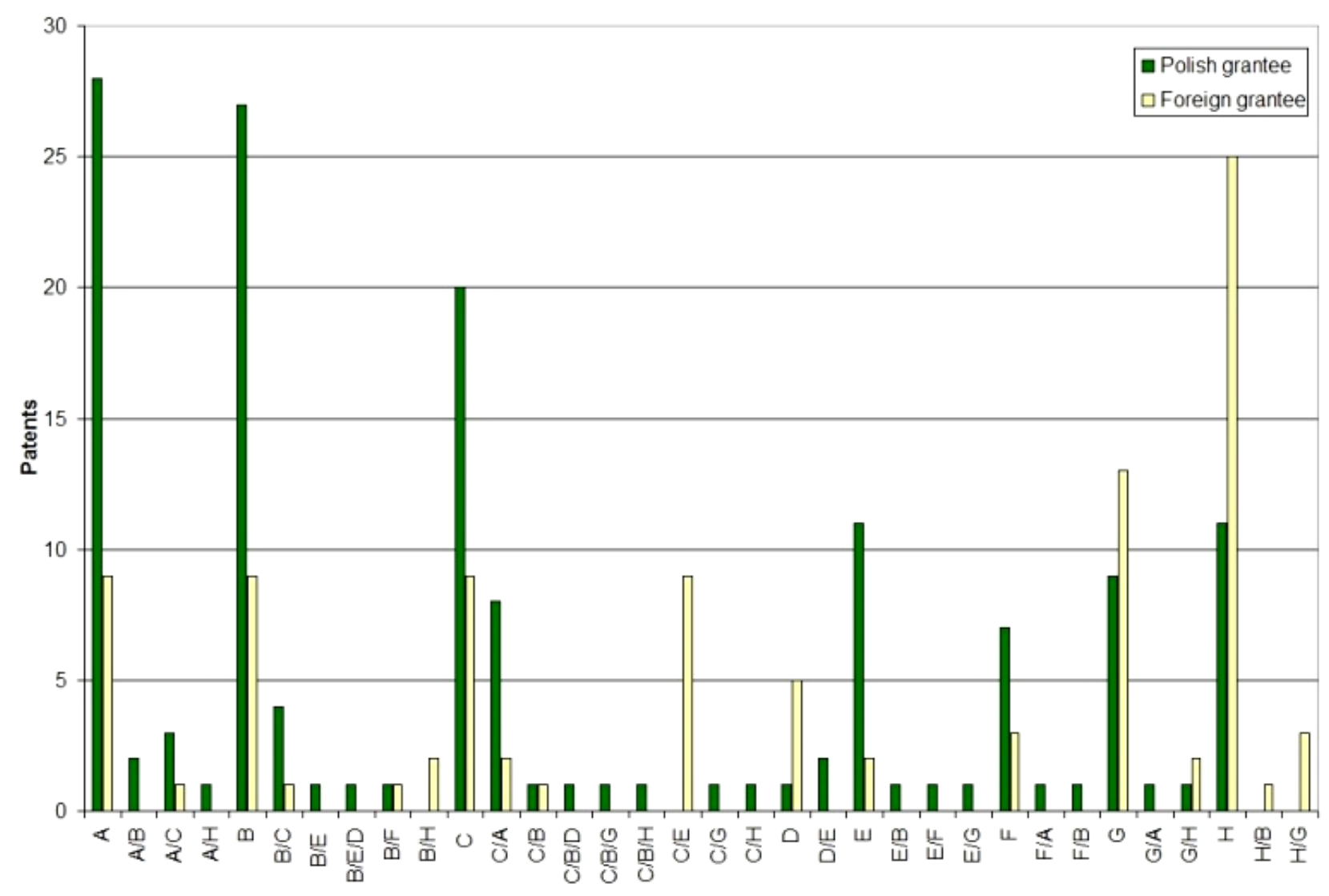

Fig. 4 European Patent Office (EPO) - Fields of technology of Polish inventors in Polish and foreign patents 2015 according to the International Patent Classification:

A - Human Necessities; B - Performing Operations, Transporting; C - Chemistry, Metallurgy; D - Textiles, Paper; E - Fixed Constructions; F - Mechanical Engineering, Lighting, Heating, Weapons, Blasting; G - Physics; 
For Polish patent grantees, Poles invent mostly for human necessities (44 patents out of 150), performing operations/transporting (42), and chemistry/metallurgy (41). For foreign patent owners, Poles invent mostly in chemistry/ metallurgy (23 patents out of 90), electricity (18) and performing operations/transporting (15).

\section{DISCUSSION}

Based on the findings presented in this study we found that awareness in Poland of intellectual property and its commercial potential is unsatisfactory. The large number of "home-grown" patents with universities as leaders, and simultaneously low interest of commerce to exploit these inventions $[3,13,14,15,19]$ lead us to the conclusion that universities patent their inventions in order to improve their rating scores at the Polish Ministry of Science and Higher Education.

Despite significant changes in the university rating scheme, there is still little internal "pressure" from technical universities on their researchers to deliver research results which are commercially feasible. At the same time, elements of academia are still reluctant to come up with utility solutions at the expense of "shelf-oriented research", which may result in an invention but will not necessarily be put into practice. Furthermore, low inventive activity is driven by bureaucracy at universities, lack of practical solutions in terms of commercialising research results, and imprecise expectations of the actors in the process: technology transfer offices, researchers and companies.

Another problem, not discussed in this paper, is lack or very little knowledge of methodologies of systematic inventive problem solving (e.g. TRIZ) at Polish technical universities [7, 12]. The teaching process at most technical universities is based on the ex-cathedra model, instead of Problem Based Learning or Learning By Doing. This leaves graduates poorly equipped to invent or innovate $[4,6,18]$.

On the other hand, the EPO statistics are very positive for the most active Polish enterprises in terms of patents, showing their potential to grow, their developing awareness of the need for IPR protection, and the need to compete in order to develop and hold the market for their products and services.

The low number of patents granted to Polish owners by the EPO, in comparison to the total granted by the UP RP, results probably from high fees for filings and applications. Additionally, the European patent procedure is time consuming and, because of that, discouraging for applicants. Presumably, the EPO cares less for the pace of patent application processing than the applicants themselves.

\section{CONCLUSIONS}

The Polish patent most of their inventions in Poland, as seen in Figure 5. Although the ratio between inventions disclosed to the UP RP and the EPO has fallen gradually, the difference is still considerable: in 2008 there were 55.8 times more patents granted by the UP RP than the EPO; in 2012, 23.1 times and in 2015, 16 times. From the point of view of the EPO, enterprises are the leading Polish patent grantees, while from the point of view of the UP RP, universities. Both at national and European levels, the most active areas of Poland in terms of inventing are Mazovian, Silesian and Lesser Poland voivodeships.

In the EPO, Polish patents are practically insignificant vs. other, comparable countries. Foreign applicants disclose their inventions mainly through the EPO, very rarely designating Poland as the country of patent protection. The number of patents with Polish (co)inventors is similar both when Polish and non-Polish grantees own them. The Poles invent mainly in four out of the eight fields categorised by the International Patent Classification, i.e.: A - human necessities, B - performing operations/transporting, C chemistry/metallurgy and $\mathrm{H}$ - electricity. When inventing abroad, they invent most often for enterprises in Switzerland, the USA and Germany.

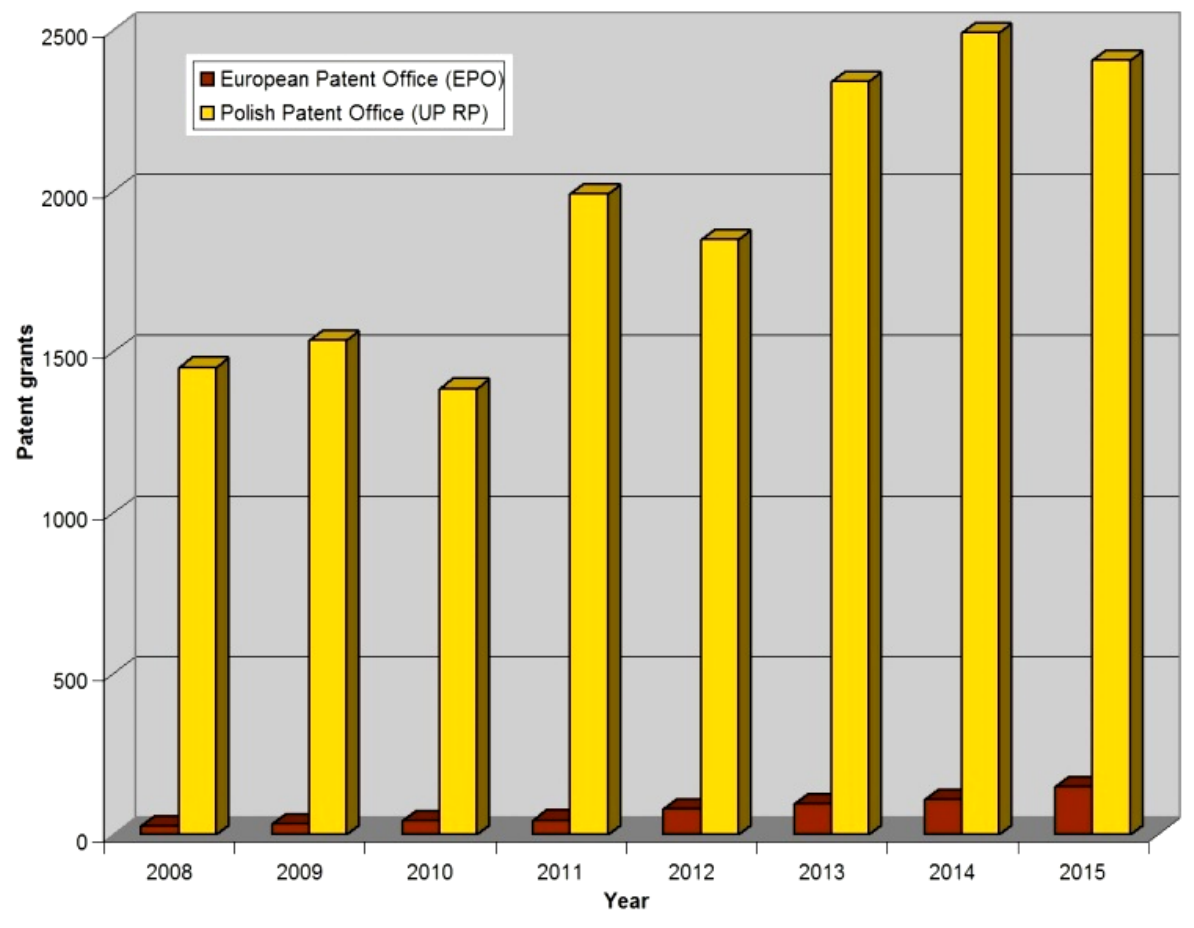


Summing up, indices for Poland suggest that it might be more innovative in the future, but there are still many challenges to overcome.

To build human capital capable of inventive problem solving which will be supportive to Polish enterprises making innovations, it is necessary to improve procedures, including those at universities, increase awareness among the university academics and management, but most of all improve the teaching process by introducing TRIZ to the curricula of Polish technical universities.

Poland has produced outstanding individuals: Copernicus, Skłodowska, Huber, Czochralski, Szczepanik, to name just a few. And it has many resources to start "a massive production of inventors". We hope that awareness and processes can align to carry on this tradition.

\section{ACKNOWLEDGEMENTS}

This publication is financed through a research grants from the Ministry of Science and Higher Education of Poland 4/S/ITESO/14: "Diagnostics methods and efficient operation of complex technical systems in terms of failure prevention and environmental protection" and 1/S/IESO/17:

"Increasing operational effectiveness of complex technical systems by systematic development and implementation of innovations using novel materials and modifying the object's structure".

\section{REFERENCES}

[1] G. Altshuller, The Innovation Algorithm: TRIZ, systematic innovation and technical creativity, 1 st ed. Worcester: Technical Innovation Center, 2007.

[2] Polish Patent Office, "Annual reports 2006-2014", Warszawa, 2015.

[3] J. Bartnicka, "Transfer of knowledge and innovations in shaping working conditions of disabled and elderly people", Scientific Journals of the Maritime University of Szczecin, vol. 103, no. 31, pp. 29-36, 2012.

[4] W. Biały, "Innovative solutions in the overhaul of the main fan of the ventillation system in a mine", Scientific Journals of the Maritime University of Szczecin, vol. 111, no. 39, pp. 25-30, 2014.

[5] Central Statistical Office, „Działalność badawcza i rozwojowa w Polsce w 2014 r.”, Warszawa, Oct. 14, 2015.

[6] L. Chybowski, D. Idziaszczyk, "Czy design thinking jest przydatny w kształceniu inżynierów?", Systemy Wspomagania $w$ Inżynierii Produkcji. Inżynieria Systemów Technicznych, vol. 8, no. 2, pp. 43-55, 2014.
[7] L. Chybowski, D. Idziaszczyk, „O antropocentrycznym i technocentrycznym podejściu w procesie tworzenia innowacji", Systemy Wspomagania w Inżynierii Produkcji. Inżynieria Systemów Technicznych, vol. 11, no. 2, pp. 51-63, 2015.

[8] European Patent Office. (2017, Jun. 22). EPO statistics for Poland [Online]. Available: https://www.epo.org/ about-us/annual-reports-statistics/statistics.html

[9] European Patent Office, "European Patent Bulletins nos. 1502-1553", Brussels, Belgium, 2015.

[10] European Commission, "Eurostat News Release", no. 209/2015, Brussels, Belgium, Nov. 30, 2015.

[11] Central Statistical Office, "Higher Education Institutions and their Finances in 2014", Warszawa, 2015.

[12] O. Mayer, "Flexible lighting distribution on "party ships", Scientific Journals of the Maritime University of Szczecin, vol. 121, no. 49, pp. 9-16, 2017.

[13] M. Molenda, "Knowledge as a determinant in developing a quality management system", Scientific Journals of the Maritime University of Szczecin, vol. 111, no. 39, pp. 116-121, 2014.

[14] Narodowy Bank Polski, „Potencjał innowacyjny gospodarki: uwarunkowania, determinanty, perspektywy”, Warszawa, May 2016.

[15] W.M. Orłowski, „Komercjalizacja badań naukowych w Polsce. Bariery i możliwości ich przełamania", PwC, Warszawa, Jul. 2013.

[16] Polish Patent Office, "Polish Patent Office Quarterly", issue 1/27/2016, 2016.

[17] Euro-Dane website. (2017, Jun. 22). Ranking największych gospodarek w Unii Europejskiej [Online]. Available: http://euro-dane.com.pl/wydarzenia-gospodarcze $-428$

[18] V.V. Souchkov. (2017, Jun. 17). Psychological Barriers and Creativity [Online]. Available: http:// www.xtriz.com/ Souchkov_PsychologicalBarriersAndCreativity.pdf

[19] R. Wolniak, "Innovation in the context of economic situation in the EU countries", Scientific Journals of the Maritime University of Szczecin, vol. 96, no. 24, pp. 141-147, 2010.

\section{mgr Dorota Chybowska}

Maritime University of Szczecin, Technology Transfer Office ul. Wały Chrobrego 1-2, 70-500 Szczecin, POLAND

e-mail: d.chybowska@am.szczecin.pl

dr hab. inż. Leszek Chybowski, prof. AM

Maritime University of Szczecin

Faculty of Marine Engineering,

ul. Wały Chrobrego1-2, 70-500 Szczecin, POLAND

e-mail: I.chybowski@am.szczecin.pl

\section{Valeri Souchkov, MSc}

University of Twente, Faculty of Engineering Technology

Drienerlolaan 5, 7522 NB Enschede, NEDERLANDS

e-mail: valeri@xtriz.com 